\title{
Tetracyclines in malaria
}

Tiphaine Gaillard ${ }^{1,2,3}$, Marylin Madamet ${ }^{2,4,5}$ and Bruno Pradines M,2,5, $^{*}$

\begin{abstract}
Malaria, a parasite vector-borne disease, is one of the greatest health threats in tropical regions, despite the availability of malaria chemoprophylaxis. The emergence and rapid extension of Plasmodium falciparum resistance to various anti-malarial drugs has gradually limited the number of potential malaria therapeutics available to clinicians. In this context, doxycycline, a synthetically derived tetracycline, constitutes an interesting alternative for malaria treatment and prophylaxis. Doxycycline is a slow-acting blood schizontocidal agent that is highly effective at preventing malaria. In areas with chloroquine and multidrug-resistant $P$. falciparum parasites, doxycycline has already been successfully used in combination with quinine to treat malaria, and it has been proven to be effective and well-tolerated. Although not recommended for pregnant women and children younger than 8 years of age, severe adverse effects are rarely reported. In addition, resistance to doxycycline is rarely described. Prophylactic and clinical failures of doxycycline have been associated with both inadequate doses and poor patient compliance. The effects of tetracyclines on parasites are not completely understood. A better comprehension of the mechanisms underlying drug resistance would facilitate the identification of molecular markers of resistance to predict and survey the emergence of resistance.
\end{abstract}

Keywords: Malaria, Plasmodium falciparum, Anti-malarial drug, Resistance, Tetracycline, Doxycycline, Prophylaxis, Treatment

\section{Background}

Malaria, a parasite vector-borne disease, is one of the greatest health threats in tropical regions, despite the availability of malaria chemoprophylaxis and the use of repellents and insecticide-treated nets. Malaria prophylaxis and chemotherapy remain a major focus of research, and new molecules are constantly being developed prior to the emergence of drug-resistant strains of the malaria parasite. The use of anti-malarial drugs is conditioned on the resistance level of Plasmodium falciparum in endemic areas, as well as the contraindications, clinical tolerance and financial costs of these drugs. Among the compounds potentially used against Plasmodium, antibiotics have been examined in vitro or in vivo.

Tetracyclines, a family of broad-spectrum antibiotics discovered in the early 1940s, are active in protozoa, including Plasmodium. In a small series of patients in 1950, tetracyclines were used to treat $P$. falciparum and Plasmodium vivax uncomplicated malaria. The

\footnotetext{
*Correspondence: bruno.pradines@free.fr

1 Unité de Parasitologie, Département d'Infectiologie de Terrain, Institut

de Recherche Biomédicale des Armées, Marseille, France

Full list of author information is available at the end of the article
}

emergence of chloroquine resistance in the 1960s led to studies conducted by the Centers for Disease Control and Prevention (CDC) and the development of the World Health Organization (WHO) recommendations that were based on the use of doxycycline for chemoprophylaxis of falciparum malaria in 1985. Currently, doxycycline is used in combination with quinine in treatment therapies and for chemoprophylaxis in multidrug resistance areas, particularly Southeast Asia. Finally, many armies use it as first-line chemoprophylaxis in areas with chloroquine resistance, including French military forces deployed in malaria-endemic areas. Since 2002, the French Army has, regrettably, had 3000 malaria cases. Recent deployments in Mali and Central African Republic showed high incidence rates, with a significant risk of contracting malaria for the 2000 soldiers. The attack rates were estimated at $7.5 \%$ in 2013 and $12.5 \%$ in 2014. These failures of prophylaxis with doxycycline are mainly associated with inadequate dosing or poor compliance. The pharmacokinetics of doxycycline, including a reduced half-life, may partly explain these failures; however, resistance phenomena may also be a factor. 


\section{Classification}

Tetracyclines are synthetic antibiotics derived from a cycline that is naturally produced by bacteria from the genus Streptomyces [1]. Tetracycline consists of three groups, based on pharmacological differences: the longacting group, which includes doxycycline and minocycline, are the most active against Plasmodium in vitro. The antibiotic action, common to all tetracycline, is bacteriostatic and inhibits bacterial protein synthesis; their spectrum of activity is large [2].

\section{Pharmacological properties}

The pharmacokinetics properties of doxycycline have been investigated in numerous studies with healthy volunteers. One important property of doxycycline is its ability to be rapidly absorbed orally; it is detectable in the blood 15-30 min after its administration [3, 4]. After an oral dose of $200 \mathrm{mg}$, peak plasma levels are obtained in approximately $2 \mathrm{~h}$; its half-life ranges from 15 to $25 \mathrm{~h}$ [5]. There are great individual variations, depending on the age of the patient and any coadministered substances [6]. Only one study of the pharmacokinetics of doxycycline was conducted during infections. It involved a case of uncomplicated malaria in combination with quinine or artesunate [7]. The authors concluded that there was a need for an initial dose of $400 \mathrm{mg}$ twice daily to maintain plasma concentrations at therapeutic levels during the treatment for malaria infection.

\section{Side effects and warnings against doxycycline}

Tetracyclines are well known for their use in treating bacterial infections, and their adverse effects have been well documented $[8,9]$. At the usual doses prescribed for malaria chemoprophylaxis, the published data are limited, and the reported adverse events vary widely. Comparative studies of the tolerance of doxycycline have been contradictory. Several retrospective studies of military teams have reported increased digestive and skin disorders and headaches with chemoprophylaxis [10-14]. A detailed analysis of studies reporting high numbers of side effects makes it possible to objectify pitfalls in the data interpretation: the dosage form is rarely specified and doxycycline is often co-administered with other substances, such as quinine. Thus, it is difficult to attribute an adverse event to cyclines only. In 1996 in sub-Saharan Africa, the French Army Health Service conducted an efficacy study of doxycycline hyclate salt versus chloroquine-proguanil [15].

Doxycycline hyclate was more efficacious than chloroquine-proguanil. However, with a $6 \%$ withdrawal rate due to gastrointestinal side effects, it was considered to be unacceptable as chemoprophylaxis. The gastrointestinal side effects (e.g., diarrhoea and epigastralgia) were attributed to the hyclate salt acidity ( $\mathrm{pH} 3$ ) and the galenic form (capsule). According to the French Drug Agency recommendations, doxycycline hyclate has been replaced by doxycycline monohydrate, a less acidic salt (pH 6) with the same bioavailability [16]. Gastrointestinal side effects, mouth ulcers, and sun sensitization occurred less frequently in the doxycycline monohydrate group than in the chloroquine-proguanil group [17]. Fifty-seven per cent of deployed Australian soldiers using mefloquine prophylaxis in East Timor reported at least one adverse effect, compared to $56 \%$ using doxycycline [18]. In Turkish troops deployed in Afghanistan, the total number of side effects in the doxycycline group was significantly higher than that in the mefloquine group [19]. However, among non-immune travellers to Sub-Saharan Africa, the total number of side effects in the doxycycline group was significantly lower compared with the chloroquine-proguanil or mefloquine groups [20].

The use of an antibiotic for several months for prophylaxis always triggers opposition from a number of bacteriologists, who note the risk of selecting resistant bacteria cyclines [21]. In 1988, a publication reported tetracycline-resistant cases of Campylobacter jejuni gastroenteritis among American soldiers based in Thailand [22]. A subsequent study by the same team showed that taking doxycycline for malaria prophylaxis resulted in less exposure to resistant bacteria than the acquisition of already resistant bacteria cyclines, which has long been widespread in this country [23]. The increase in multidrugresistant gram-negative bacteria colonization among US military personnel in Afghanistan is likely due to environmental exposures rather than doxycycline exposure [24]. Methicillin-susceptible Staphylococcus aureus and methicillin-resistant Staphylococcus aureus colonization of military personnel under deployment was not associated with doxycycline exposure [25]. However, outbreaks of Panton-Valentine leukocidin-positive, doxycycline resistant, methicillin-susceptible Staphylococcus aureus infections associated with doxycycline prophylaxis have been reported in the French Army at the Ivory Coast [26]. Except for these military clinical cases, no study has been published about the risk of bacterial resistance to tetracyclines associated with their prophylaxis use. Doxycycline is contraindicated in patients with allergies to tetracyclines, pregnant women (from the second trimester of pregnancy due to the risk of abnormal tooth bud) and children under 8 years of age because of the risk of discolouration and enamel hypoplasia.

\section{Mechanism of action}

Cyclines are a family of antibiotics that act by inhibiting bacterial protein synthesis. Their mechanisms of action have been described at the molecular level [27]. Cyclines 
act by binding to several proteins in the $30 \mathrm{~S}$ ribosomal small subunit and to different ribonucleic acids in the $16 \mathrm{~S}$ ribosomal RNA. Their mechanisms of action on Plasmodium have not been as well described, although a number of studies have addressed this issue. There are three categories of ribosomes in Plasmodium: mitochondrial, plastid and nuclear [28]. As suggested by three studies [29-31], tetracycline may directly inhibit mitochondrial protein synthesis and also decrease the activity of a mitochondrial enzyme (i.e., dihydroorotate dehydrogenase) involved in de novo pyrimidine synthesis [32]. Doxycycline inhibits the synthesis of nucleotides and deoxynucleotides in P. falciparum [33], but the concentration used $(200 \mu \mathrm{M})$ is much higher than that used clinically. In vitro exposure of $P$. falciparum to minocycline also decreases the transcription of mitochondrial genes (subunit I of cytochrome c oxidase and apocytochrome b) and apicoplast genes (subunit rpoB/C of RNA polymerase), suggesting some activity with these two organelles [34]. A more recent study [35] has shown that doxycycline would specifically act on the apicoplast of $P$. falciparum and, to a lesser extent, on the mitochondrial whose division is inhibited at the end of the cycle; according to the authors, this finding could be attributed to the apicoplastic target (the two organelles present common metabolic pathways). The most recently published study confirms the action of doxycycline on the apicoplast in two stages, with an immediate toxic effect and a toxic effect (measurable after cell division): the first effect is considered to be nonspecific, acting on collateral targets that are not located in the apicoplast; the second effect is characteristic of cell death, as observed after an offset effect on the apicoplast [36]. A proteomic approach confirmed the specific deregulation of the proteins involved in apicoplast metabolism after doxycycline treatment [37].

\section{Antiplasmodial activities Activity on sporogony}

All studies of the antiplasmodial activity of doxycycline have shown that this molecule, at a dose of $100 \mathrm{mg}$ daily, was a schizonticide agent, with a slow-acting duration [1]. The lack of an in vivo effect of tetracyclines on the development of gametocytes, suggested by Ruiz Sanchez [38, 39], was confirmed by a study performed in 1971 with healthy volunteers infected with $P$. falciparum or $P$. vivax and treated using tetracycline or doxycycline [40]. Tetracyclines have no effect on the sporogony in Anopheles: they do not reduce the infectivity of mosquitoes infected with gametocyte carriers under treatment [41].

\section{Activity on hepatic forms}

Several in vivo studies performed with simian models (rhesus monkeys and chimpanzees) infected by
Plasmodium cynomolgi bastianellii, P. vivax or P. cynomolgi ceylonensis have shown that terramycin, minocycline or demeclocycline also affected their hepatic forms [42-44]. In a murine model, doxycycline also proved to be effective in the hepatic stages of Plasmodium berghei and Plasmodium yoelii yoelii [45], as the administration of $1.4 \mathrm{mg}$ of doxycycline simultaneously or $3 \mathrm{~h}$ after the injection of sporozoites prevented the appearance of a parasitaemia in $100 \%$ of the rodents $(n=10)$, while the untreated controls became infected.

However, the activity of doxycycline on the liver forms of $P$. falciparum was demonstrated to be partially effective in several studies of the hepatic forms of P. falciparum $[46,47]$. Of the twelve subjects who received $100 \mathrm{mg}$ of doxycycline per day for 3 days prior to exposure to infected mosquitoes and for the six following days, four developed malaria [46]. Moreover, the regular uptake of doxycycline did not alter the level of antibodies against the pre-erythrocytic stages of P. falciparum [48]. The findings of these studies have justified the recommendation of the currently approved doxycycline regimen (i.e., once daily for 4 weeks after returning from an endemic area).

\section{Activity on erythrocytic forms}

According to Geary et al. [49], cyclines are active during the three developmental asexual erythrocytic stages of $P$. falciparum, equivalently. According to Dahl et al. [35], the aged trophozoites and young schizonts were more susceptible to doxycycline than the young trophozoites and older schizonts, with a dose and time-dependent relationship observed for the effectiveness of the doxycycline on erythrocytic stages. The effectiveness of doxycycline on the erythrocytic stages is evaluated by identifying the concentration necessary to inhibit the growth of $50 \%$ of the parasites, or the $\mathrm{IC}_{50}[50,51]$. When comparing the $\mathrm{IC}_{50}$ value of doxycycline to the values of other antimalarial drugs, which are sub-micromolar, doxycycline appears to be much less active. Considering its delayed onset of action [52, 53], this finding justifies its therapeutic use in combination with a fast schizonticide.

\section{Clinical effectiveness}

Among tetracyclines, doxycycline is the only one recommended as an anti-malarial prophylaxis [41]. In 1994, 34 years after its development, doxycycline was approved as prophylaxis against malaria by the Food and Drug Administration. In multidrug resistance zones, doxycycline is used as malaria chemoprophylaxis against $P$. falciparum at a dose of $100 \mathrm{mg} /$ day starting at the day of arrival in endemic areas and continuing for up to 4 weeks after returning. This scheme was originally recommended by the WHO in 1985, based on the previously mentioned 
studies $[40,41]$. The primary studies (Table 1 ) of the effcacy and safety of doxycycline prophylaxis were performed with different populations living in endemic areas [54-58] and non-immune travellers, primarily soldiers from different armies [15, 47, 59]. Most of the failures observed in the prophylaxis of falciparum malaria were related either to inadequate dosages (confirmed by low plasma concentrations of doxycycline) [60], the use of half-doses [55] or poor adherence [59, 61-63]. True prophylactic failures (verified by plasma dosage of doxycycline) are rarely reported. Two Australian soldiers presented with falciparum malaria 2 weeks after returning from Papua New Guinea, despite good adherence [59]. In vitro chemosensitivity tests to doxycycline were not performed in these cases. However, the prophylaxis was stopped 3 days after returning from the endemic area; the recommendation is that prophylaxis should be continued 4 weeks after returning. There has been one recent report of the death of a French soldier due to a prophylaxis failure caused by doxycycline resistance [64]. Cyclines are inactive on hypnozoites. Indeed, the occurrence of malaria caused by $P$. vivax or $P$. ovale returning from an endemic area requires a radical cure with primaquine [65].

Doxycycline at a dose of $100 \mathrm{mg} /$ day starting at the day of arrival in endemic areas and continuing for up to 4 weeks after returning, still remains highly effective as $P$. falciparum prophylaxis. Concerning the treatment of malaria, studies conducted in the 1950s $[28,39]$ and in 1970 [40, 41, 66, 67] have shown the effectiveness of cycline monotherapy in treating simple access to $P$. falciparum. Later, the need for a minimum 7-day treatment was demonstrated; the disappearance of parasites was effective only after 5 days at a dose of $200 \mathrm{mg}$ daily [68].

With the risk of rapid progression from uncomplicated Plasmodium falciparum malaria to severe disease and the slow schizonticide action of the cyclines, they should not be used as monotherapy (Table 2). Their combination with other anti-malarial drugs has been studied many times, particularly in areas of multidrug resistance, such as Southeast Asia (Table 3) [69-73]. The most described associations are doxycycline $(200 \mathrm{mg})$ with quinine $(10 \mathrm{mg} / \mathrm{kg} /$ day $)$ for 7 days, which operates with a therapeutic efficacy of $91-100 \%$ in multi-resistant areas, even if the in vitro susceptibility of isolates to quinine is decreasing [74]. All other tested associations are lower or equal in terms of their efficacy, parasite clearance or resolution of fever, and they are often more expensive.

Due to its slow schizonticide action and short halflife, doxycycline should not be use in monotherapy in the treatment of uncomplicated malaria. Doxycycline remains still effective in combination with quinine or artesunate at a dose of $200 \mathrm{mg}$ for 7 days.

Table 1 Efficacy of doxycycline for prophylaxis against $P$. falciparum malaria

\begin{tabular}{|c|c|c|c|c|c|c|c|c|c|c|}
\hline Year & Place & References & Pop & Number & Drug & Route & Dose/d & Other drug & Duration/d & Efficacity \\
\hline 1987 & Thailand & Pang [54] & C & 95 & D & $\mathrm{PO}$ & 50 or $100 \mathrm{mg}^{\mathrm{a}}$ & / & 35 & 94.7 \\
\hline 1988 & Thailand & Pang [55] & C & 67 & D & $\mathrm{PO}$ & 50 or $100 \mathrm{mg}^{\mathrm{a}}$ & / & 97 & 97.0 \\
\hline 1988 & Thailand & Pang [55] & C & 77 & D & $\mathrm{PO}$ & 25 or $50 \mathrm{mg}^{\mathrm{a}}$ & / & 107 & 97.4 \\
\hline 1989 & Thailand & Watanasook [56] & A & 243 & D & $\mathrm{PO}$ & $50 \mathrm{mg}$ & / & 119 & 92.6 \\
\hline 1989 & Thailand & Watanasook [56] & A & 243 & D & $\mathrm{PO}$ & $100 \mathrm{mg}$ & / & 119 & 84.4 \\
\hline 1992 & Thailand & Shanks [57] & A & 77 & D & $\mathrm{PO}$ & $100 \mathrm{mg}$ & / & 80 & 96.1 \\
\hline 1993 & New Guinea & Rieckmann [47] & A & 60 & D & $\mathrm{PO}$ & $100 \mathrm{mg}$ & / & 42 & 100 \\
\hline 1993 & New Guinea & Rieckmann [47] & A & 69 & D & $\mathrm{PO}$ & $100 \mathrm{mg}$ & $P R$ & 21 & 100 \\
\hline 1993 & New Guinea & Rieckmann [47] & A & 125 & D & $\mathrm{PO}$ & $50 \mathrm{mg}$ & $\mathrm{CQ}$ & 91 & 100 \\
\hline 1995 & Kenya & Weiss [60] & C & 32 & D & $\mathrm{PO}$ & $50 \mathrm{mg}$ & / & 77 & 84 \\
\hline 1995 & Somalia & Shanks [63] & A & 900 & D & $\mathrm{PO}$ & $100 \mathrm{mg}$ & / & 135 & 99.9 \\
\hline 1995 & Cambodia & Shanks [63] & A & 600 & D & $\mathrm{PO}$ & $100 \mathrm{mg}$ & $\mathrm{CQ}$ & 195 & 99.7 \\
\hline 1995 & New Guinea & Shanks [59] & $A$ & 53 & D & $\mathrm{PO}$ & $100 \mathrm{mg}$ & PR & 42 & 96.2 \\
\hline 1997 & Irian Jaya & Ohrt [103] & A & 67 & D & $\mathrm{PO}$ & $100 \mathrm{mg}$ & / & 87 & 99 \\
\hline 1998 & Kenya & Andersen [104] & A & 70 & D & $\mathrm{PO}$ & $100 \mathrm{mg}$ & / & 70 & 92.6 \\
\hline 1999 & Irian Jaya & Taylor [58] & A & 75 & D & $\mathrm{PO}$ & $100 \mathrm{mg}$ & / & 140 & 96.3 \\
\hline 1999 & Gabon +CAR & Baudon [15] & $A$ & 171 & D & $\mathrm{PO}$ & $100 \mathrm{mg}$ & / & 150 & 97.1 \\
\hline 1999 & Ethiopia & Schwartz [105] & A & 19 & D & $\mathrm{PO}$ & $100 \mathrm{mg}$ & / & / & 94.7 \\
\hline 2002 & Eastern Timor & Peragallo [106] & A & 280 & D & $\mathrm{PO}$ & $100 \mathrm{mg}$ & $P R$ & 168 & 98.4 \\
\hline 2005 & Afghanistan & Sonmez [19] & A & 986 & $\mathrm{D}$ & $\mathrm{PO}$ & $100 \mathrm{mg}$ & / & 84 & 100 \\
\hline
\end{tabular}

Pop population, $A$ adults, $C$ children, $D$ doxycycline, $C Q$ chloroquine, $P R$ primaquine

a According to weight ( $<$ or $>40 \mathrm{~kg}$ ) 
Table 2 Clinical trials of doxycycline monotherapy against $P$. falciparum malaria

\begin{tabular}{|c|c|c|c|c|c|c|c|c|c|}
\hline \multicolumn{5}{|c|}{ Study demographic details } & \multicolumn{5}{|l|}{ Regimen } \\
\hline Year & Place & References & Population & $\mathrm{Nb}$ & Dosage/d & Nb doses/d & Route & Nb days & Efficacy (\%) \\
\hline 1971 & USA & Clyde [107] & A & 4 & $200 \mathrm{mg}$ & 2 & $\mathrm{PO}$ & 4 & NR \\
\hline 1971 & USA & Clyde [107] & A & 9 & $200 \mathrm{mg}$ & 2 & $\mathrm{PO}$ & 7 & $N R$ \\
\hline 1981 & West Malaysia & Ponnampalam [68] & C & 9 & $4 \mathrm{mg} / \mathrm{kg}$ & $N R$ & $\mathrm{PO}$ & 4 & 44.4 \\
\hline 1981 & West Malaysia & Ponnampalam [68] & C & 26 & $4 \mathrm{mg} / \mathrm{kg}$ & $N R$ & $\mathrm{PO}$ & 7 & 84.6 \\
\hline 2001 & Indonesia & Taylor [108] & $A$ & 20 & $200 \mathrm{mg}$ & 2 & $\mathrm{PO}$ & 7 & 64.7 \\
\hline
\end{tabular}

$A$ adults, $C$ children, $N R$ not reported

\section{Mechanism of resistance to doxycycline}

The notion of $P$. falciparum resistance to doxycycline is a tricky concept to grasp. Treatment failures reported with quinine plus doxycycline are rare events. The only drug pressure with cycline on Plasmodium was performed in a murine model of Plasmodium berghei [75]. The administration of increasing doses of minocycline to mice infected with $1 \times 10^{7}$ parasites for 86 successive passages over 600 days made it possible to obtain a resistant $P$. berghei strain, with a median drug inhibitory concentration $\left(\mathrm{IC}_{50}\right)$ of $600 \mathrm{mg} / \mathrm{kg} /$ day, which is sixfold higher than that of the susceptible starting strain $(100 \mathrm{mg} / \mathrm{kg} /$ day $)$.

In addition, few studies have evaluated the $P$. falciparum in vitro susceptibility to doxycycline. However, several studies of isolates from different continents have established different groups of in vitro susceptibility based on $\mathrm{IC}_{50}$ doxycycline assessments. But, in the absence of standardized ex vivo and in vitro tests, it is difficult to compare data from different laboratories. Indeed, $\mathrm{IC}_{50}$ values and cut-off for in vitro resistance are specific to the methodology. For example, the in vitro effects and the $\mathrm{IC}_{50}$ values for doxycycline are dependent upon the time incubation conditions [52, 53], gas conditions (i.e., $\mathrm{O}_{2}$ and $\mathrm{CO}_{2}[76,77]$ and methodology (i.e., an isotopic test versus an immunoenzymatic test) [78]. These differences in methodology must be taken account for comparing and analysing resistance data from different works.

A 2010 publication, with reported values of doxycycline $\mathrm{IC}_{50}$ on 747 isolates of $P$. falciparum in Africa over a period of 9 years (1996-2005), found a trimodal distribution of $\mathrm{IC}_{50}$ with three susceptibility levels identified [79]. Nine isolates (1.2\%) exceeded the threshold of $35 \mu \mathrm{M}$ identifying isolates, with reduced susceptibility to doxycycline. Another evaluation on 484 isolates of imported $P$. falciparum parasites between 2006 and 2010 , based on the same methodology, showed that $2.7 \%$ had reduced susceptibility to doxycycline [80]. In a study published in 2013, on 113 isolates from Senegal, 9 (8.0\%) isolates exhibited $\mathrm{IC}_{50}$ over the limit of $35 \mu \mathrm{M}$ [81]. In
2009-2010 and 2010-2011, 12 and $10.3 \%$ of P. falciparum isolates collected in Dakar showed reduced susceptibility to doxycycline in comparable methodology (cut off of $37 \mu \mathrm{M})[78,82]$. A study in Kenya showed that $15 \%$ of the isolates had an $\mathrm{IC}_{50}>35 \mu \mathrm{M}$ [83]. A recent study on 620 Thai isolates found a bimodal distribution [84]. The two groups identified presented with a mean value of $13.15 \mu \mathrm{M}$ for the group of 591 isolates with low $\mathrm{IC}_{50}$ and a mean value of $31.60 \mu \mathrm{M}$ for the group of high $\mathrm{IC}_{50}$, including 29 isolates. Only seven isolates of 620 (1.1\%) had doxycycline $\mathrm{IC}_{50}$ values that were superior to $35 \mu \mathrm{M}$. In 2008, a study performed in French Guiana investigated the prevalence of isolates with reduced susceptibility to doxycycline and found from 15 to $25 \%$ of the isolates from 1996 to 2001, $51 \%$ in 2002, to $61.5 \%$ in 2003 and to more than $67 \%$ in 2005 [50]. The low threshold of susceptibility of $9.6 \mu \mathrm{M}$ chosen can explain this high level of in vitro resistance. As the methodology is the same as that subsequently used, the prevalence of reduced susceptibility can be recalculated with a cut off at $35 \mu \mathrm{M}$ : the prevalences ranged from 0 to $4.8 \%$ (0\% in 1997, 1999, 2000, 2003 and 2004, $1.8 \%$ in 1998, $4.8 \%$ in 2001, $2.2 \%$ in 2002 and $1.9 \%$ in 2005). A Ghanaian study performed in 2012 recorded a surprisingly high level of resistance (i.e., $23.7 \%$ ) for doxycycline [85], with a threshold $\mathrm{IC}_{50}$ value of $35 \mu \mathrm{M}$. This finding could be explained by the use of SYBR Green 1-based in vitro test applied to assess the susceptibility of clinical isolates. Indeed, Wein et al. demonstrated that doxycycline $\mathrm{IC}_{50}$ values were significantly higher in fluorescence-based SYBR green assays than in isotopic or HRP2-based tests [86]. However, despite the lack of standardization for the evaluation of doxycycline $\mathrm{IC}_{50}$, the existence of a high $\mathrm{IC}_{50}$ group is indisputable.

The search on the potential mechanisms of the resistance of $P$. falciparum to doxycycline focuses on two ways: the exploration of plasmodial genes homologue to bacterial genes that are involved in bacterial resistance to doxycycline and the exploration of genes coding apicoplastic proteins which could be targets for doxycycline. Different hypotheses have been published 


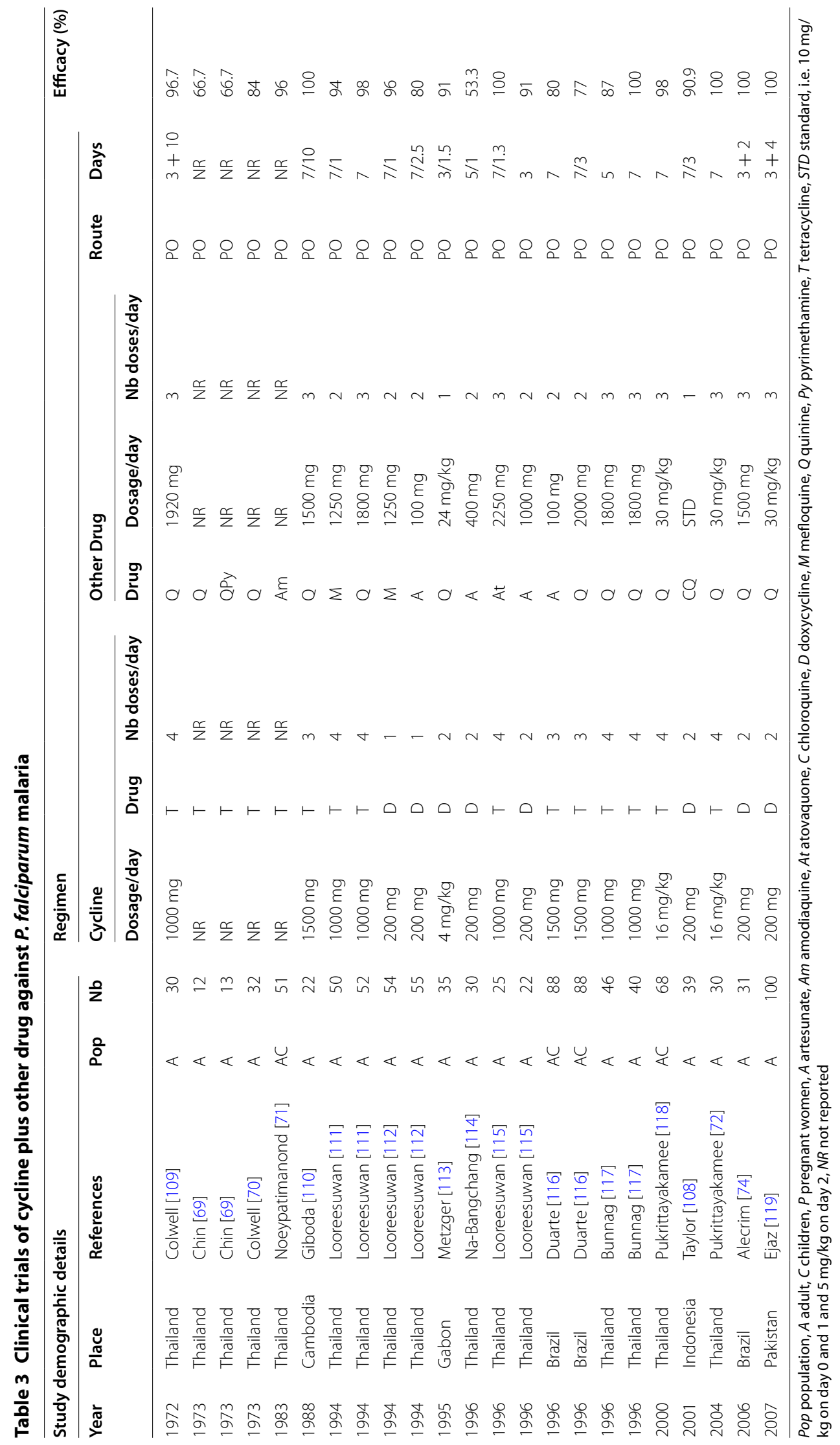


regarding the potential mechanisms of the resistance of $P$. falciparum to doxycycline correlated to the bacterial world. Several mechanisms of bacterial resistance to the cyclines have been identified [21]: (1) tet efflux protein genes encode for membrane-associated proteins that export tetracycline from the cell, reducing the intracellular drug concentration and thus protecting the ribosomes [87]; (2) TetX protein, a flavin-dependent monooxygenase, degrades tetracycline in vitro and in vivo [88]; and (3) ribosomal protection proteins in the cytoplasm protect ribosomes from the action of tetracycline in a GTP-dependent manner [89, 90]. Analogues of these proteins have been identified in P. falciparum [91]. Sequence analysis of 11 genes (pftufA, pfEF-TS, pfmdt, pftetQ, pfrps3, pfrps7, pfrps8, pfrps9, pfrps11, pfrps14, and $p f r p s 17$ ) and evaluation of $p f m d t$ and $p f t e t Q$ copy numbers were conducted using 90 isolates from 14 African countries [51]. It has been demonstrated that no polymorphism was found in a small subunit of apicoplastic ribosomal genes (pfrps7, pfrps9, and pfrps17, although S7, S9, and S17) and that the copy number increases of two genes, $P$. falciparum metabolite drug transporter gene (pfmdt, PFE0825w), a membrane transporter with similarities to the bacterial efflux pumps, and $P$. falciparum GTPase TetQ gene (pfTetQ, PFL1710c), similar to the bacterial ribosomal protein TetA involved in tetracycline resistance, were associated with reduced susceptibility to doxycycline in P. falciparum [51]. The number of parasites that is classed as in vitro resistant is very small, and unfortunately, that means that small random changes may be associated without being causal. However, this association was later confirmed using 89 African imported isolates [80]. In addition, PfTetQ KYNNNN motif repeats of $<3$ are predictive of in vitro resistant $P$. falciparum parasites with $\mathrm{IC}_{50}>35 \mu \mathrm{M}$ (odds ratio 15) [83]. The involvement of the copy numbers of $p f m d t$ and the PfTetQ KYNNNN motif repeats in reduced susceptibility to doxycycline was confirmed by the doxycycline prophylactic failure from the Central African Republic (i.e., the doxycycline failure in a compliant patient, as confirmed by a statement of correct intake of doxycycline and the presence of an expected plasmatic concentration of doxycycline), which was associated with two copies of the Pfmdt gene, as well as the two KYNNNN motif repeats [64]. However, these molecular markers were certainly not the only involved in cases of reduced susceptibility to doxycycline. A study of Senegalese isolates showed a lack of association between the number of copies of $p f m d t$ and pftetQ and high $\mathrm{IC}_{50}$ for doxycycline, essentially because of an insufficient number of isolates with high $\mathrm{IC}_{50}$ [81]. There was an absence of association between the number of copies of $p f m d t$ and $p f t e t Q$ or the polymorphisms on $p f t e t Q$ and susceptibility to doxycycline in P. falciparum isolates from Thailand and French Guiana [84, 92]. Copy number of $p f m d t$ and $p f t e t Q$ and polymorphisms on pftet $Q$ are not sufficient to explain reduced susceptibility to doxycycline, which may be multigenic.

Other hypotheses were explored. Through homology with the bacterial world, the exploration of new apicoplast genes has been performed, and in particular, the association between the polymorphism of the small subunit ribosomal RNA gene, pfssrRNA, and in vitro susceptibility to doxycycline was investigated [93]. In Helicobacter pylori, tetracycline resistance has not been associated with efflux or ribosomal protection proteins; instead, it was attributed to mutations in the 16S rRNAencoding genes that affect the binding site of tetracycline $[94,95]$. Tetracycline resistance mediated by mutations in the 16S rRNA was first found in Propionibacterium acnes, and a mutation from $\mathrm{G}$ to $\mathrm{C}$ was reported at position 1058 (Escherichia coli numbering) in their $16 \mathrm{~S}$ rRNA genes [96]. A triplet mutation in the same 16S rRNA domain (965-967; E. coli numbering) was also found [90, 95, 97, 98]. Because the apicoplast contains an independent genome, encoding prokaryote-like RNA polymerase subunits, $70 \mathrm{~S}$ ribosomal subunits, tRNAs and a small number of proteins [99], it was interesting to investigate the mechanism of bacterial resistance of $P$. falciparum to doxycycline. Moreover, comparative analyses of the $P$. falciparum genome revealed that the nucleic acid sequence of a small subunit of ribosomal RNA gene belonging to the apicoplast shares 58 and $62 \%$ of their identities with the 16S rRNA gene from Propionibacterium acnes and Helicobacter pylori, respectively. However, the sequencing of the small subunit ribosomal RNA gene (PFC10_ API0057) in P. falciparum African and Thaï isolates did not reveal any mutation, regardless of the determined $\mathrm{IC}_{50}$ values [93].

Another hypothesis to be explored is the role of plasmodial apicoplast genes, that bacterial homologues are not involved in bacterial resistance to doxycycline, such as arps10, could be involved in artemisinin resistance [100] by encoding the apicoplast ribosomal protein S10 precursor, as well as $f d$, by encoding the ferredoxin protein, a key component of the apicoplast electron transport chain. These apicoplast genes could also be involved in the decreased susceptibility of P. falciparum to doxycycline because of doxycycline mode of action.

However, the better way to identify the potential genes involved in reduced susceptibility to doxycycline is to create in vitro resistant parasites in cultivation by drug pressure and then to sequence and analyse the whole genome of the both original susceptible strain and resistant strain as it was successfully previously done for the artemisinin resistance [101, 102]. 


\section{Conclusions}

The emergence and rapid extension of $P$. falciparum resistance to principal anti-malarial drugs necessitates the search for new molecules. In addition, doxycycline (in combination with quinine) is an excellent candidate for the treatment of uncomplicated malaria and as prophylaxis in multi-resistant areas. The adequate tolerance and efficacy of cyclines have been demonstrated. A better comprehension of the mechanisms of action and resistance would facilitate the design of more effective structural analogues and the identification of molecular markers of resistance to predict and survey the emergence of resistance.

\section{Authors' contributions}

TG, MM and BP drafted the manuscript. All authors read and approved the final manuscript.

\begin{abstract}
Author details
${ }^{1}$ Unité de Parasitologie, Département d'Infectiologie de Terrain, Institut de Recherche Biomédicale des Armées, Marseille, France. ${ }^{2}$ Unité de Recherche sur les Maladies Infectieuses et Tropicales Emergentes, UM 63, CNRS 7278, IRD 198, Inserm 1095, Aix Marseille Université, Marseille, France. ${ }^{3}$ Fédération des Laboratoires, Hôpital d'Instruction des Armées Saint Anne, Toulon, France. ${ }^{4}$ Equipe Résidente de Recherche en Infectiologie Tropicale, Institut de Recherche Biomédicale des Armées, Hôpital d'Instruction des Armées, Marseille, France. ${ }^{5}$ Centre National de Référence du Paludisme, Marseille, France. ${ }^{6}$ Unité de Parasitologie et d'Entomologie, Département des Maladies Infectieuses, Institut de Recherche Biomédicale des Armées, Brétigny sur Orge, France.
\end{abstract}

\section{Competing interests}

The authors declare that they have no competing interests.

Received: 30 June 2015 Accepted: 2 November 2015

Published online: 10 November 2015

\section{References}

1. Tan KR, Magill AJ, Parise ME, Arguin PM. Doxycycline for malaria chemoprophylaxis and treatment: report from the CDC expert meeting on malaria chemoprophylaxis. Am J Trop Med Hyg. 2011;84:517-31.

2. Gialdroni Grassi G. Tetracyclines-extending the atypical spectrum. Int J Antimicrob Agents. 1993;3:31-46.

3. Cunha BA, Sibley CM, Ristuccia AM. Doxycycline. Ther Drug Monit. 1982;4:115-35.

4. Saivin S, Houin G. Clinical pharmacokinetics of doxycycline and minocycline. Clin Pharmacokinet. 1988;15:355-66.

5. Welling PG, Koch PA, Lau CC, Craig WA. Bioavailability of tetracycline and doxycycline in fasted and nonfasted subjects. Antimicrob Agents Chemother. 1977;11:462-9.

6. Maibach $\mathrm{H}$. Second-generation tetracyclines, a dermatologic overview: clinical uses and pharmacology. Cutis. 1991;48:411-7.

7. Newton PN, Chaulet J-F, Brockman A, Chierakul W, Dondorp A, Ruangveerayuth $\mathrm{R}$, et al. Pharmacokinetics of oral doxycycline during combination treatment of severe falciparum malaria. Antimicrob Agents Chemother. 2005;49:1622-5.

8. Driscoll MS, Rothe MJ, Abrahamian L, Grant-Kels JM. Long-term oral antibiotics for acne: is laboratory monitoring necessary? J Am Acad Dermatol. 1993;28:595-602.

9. Delaney TJ, Leppard BJ, MacDonald DM. Effects of long term treatment with tetracycline. Acta Derm Venereol. 1974;54:487-9.

10. Sánchez JL, DeFraites RF, Sharp TW, Hanson RK. Mefloquine or doxycycline prophylaxis in US troops in Somalia. Lancet. 1993;341:1021-2.
11. Shamiss A, Atar E, Zohar L, Cain Y. Mefloquine versus doxycycline for malaria prophylaxis in intermittent exposure of Israeli Air Force aircrew in Rwanda. Aviat Space Environ Med. 1996;67:872-3.

12. Wallace MR, Sharp TW, Smoak B, Iriye C, Rozmajzl P, Thornton SA, et al. Malaria among United States troops in Somalia. Am J Med. 1996;100:49-55.

13. Conrad KA, Kiser WR. Doxycycline vs. mefloquine. Mil Med. 1997;162:viii.

14. Korhonen C, Peterson K, Bruder C, Jung P. Self-reported adverse events associated with antimalarial chemoprophylaxis in peace corps volunteers. Am J Prev Med. 2007;33:194-9.

15. Baudon D, Martet G, Pascal B, Bernard J, Keundjian A, Laroche R. Efficacy of daily antimalarial chemoprophylaxis in tropical Africa using either doxycycline or chloroquine-proguanil; a study conducted in 1996 in the French Army. Trans R Soc Trop Med Hyg. 1999;93:302-3.

16. Malmborg AS. Bioavailability of doxycycline monohydrate. A comparison with equivalent doses of doxycycline hydrochloride. Chemother. 1984:30:76-80.

17. Pages F, Boutin JP, Meynard JB, Keundjian A, Ryfer S, Giurato L, et al. Tolerability of doxycycline monohydrate salt vs. chloroquine-proguanil in malaria chemoprophylaxis. Trop Med Int Health. 2002;7:919-24.

18. Kichener SJ, Nasveld PE, Gregory RM, Edstein MD. Mefloquine and doxycycline malaria prophylaxis in Australian soldiers in East Timor. Med J Aust. 2005;182:168-71.

19. Sonmez A, Harlak A, Kilic S, Polat Z, Hayat L, Keskin O, et al. The efficacy and tolerability of doxycycline and mefloquine in malaria prophylaxis of the ISAF troops in Afghanistan. J Infect. 2005;51:253-8.

20. Schlagenfauf $P$, Tschopp A, Johnson R, Nothdurft HD, Beck B, Schwartz E, et al. Tolerability of malaria chemoprophylaxis in non-immune travellers to sub-Saharan Africa: multicentre, randomised, double blind, for arm study. BMJ. 2003;327:1-6.

21. Chopra I, Roberts M. Tetracycline antibiotics: mode of action, applications, molecular biology, and epidemiology of bacterial resistance. Microbiol Mol Biol Rev. 2001;65:232-60.

22. Taylor DN, Pitarangsi C, Echeverria P, Diniega BM. Campylobacter enteritis during doxycycline prophylaxis for malaria in Thailand. Lancet. 1988;2:578-9.

23. Arthur JD, Echeverria P, Shanks GD, Karwacki J, Bodhidatta L, Brown JE. A comparative study of gastrointestinal infections in United States soldiers receiving doxycycline or mefloquine for malaria prophylaxis. Am J Trop Med Hyg. 1990;43:608-13.

24. Vento TJ, Cole DW, Mende K, Calvano TP, Rini EA, Tully C, et al. Multidrugresistant fram-negative bacteria colonization of healthy US military personnel in the US and Afghanistan. BMC Infect Dis. 2013;13:68.

25. Vento TJ, Cole DW, Mende K, Calvano TP, Rini EA, Tully C, et al. Staphylococcus aureus colonization of healthy military service members in the United States and Afghanistan. BMC Infect Dis. 2013;13:325.

26. Lesens O, Haus-Cheymol R, Dubrous P, Verret C, Spiegel A, Bonnet R, et al. Methicillin-susceptible, doxycycline-resistant Staphylococcus aureus, Côte d'Ivoire. Emerg Infect Dis. 2007;13:488-90.

27. Roberts MC. Tetracycline resistance determinants: mechanisms of action, regulation of expression, genetic mobility, and distribution. FEMS Microbiol Rev. 1996;19:1-24.

28. Sharma I, Sullivan M, McCutchan TF. The in vitro anti-malarial activity of novel semi synthetic nocathiacin I antibiotics. Antimicrob Agents Chemother. 2015:59:3174-9.

29. Blum JJ, Yayon A, Friedman S, Ginsburg H. Effects of mitochondrial protein synthesis inhibitors on the incorporation of isoleucine into Plasmodium falciparum in vitro. J Protozool. 1984;31:475-9.

30. Kiatfuengfoo R, Suthiphongchai T, Prapunwattana P, Yuthavong Y. Mitochondria as the site of action of tetracycline on Plasmodium falciparum. Mol Biochem Parasitol. 1989;34:109-15.

31. Budimulja AS, Syafruddin, Tapchaisri P, Wilairat P, Marzuki S. The sensitivity of Plasmodium protein synthesis to prokaryotic ribosomal inhibitors. Mol Biochem Parasitol. 1997:84:137-41.

32. Prapunwattana P, O'Sullivan WJ, Yuthavong Y. Depression of Plasmodium falciparum dihydroorotate dehydrogenase activity in in vitro culture by tetracycline. Mol Biochem Parasitol. 1988;27:119-24.

33. Yeo AE, Edstein MD, Shanks GD, Rieckmann KH. Potentiation of the antimalarial activity of atovaquone by doxycycline against Plasmodium falciparum in vitro. Parasitol Res. 1997;83:489-91. 
34. Lin Q, Katakura K, Suzuki M. Inhibition of mitochondrial and plastid activity of Plasmodium falciparum by minocycline. FEBS Lett. 2002;515:71-4.

35. Dahl EL, Shock JL, Shenai BR, Gut J, DeRisi JL, Rosenthal PJ. Tetracyclines specifically target the apicoplast of the malaria parasite Plasmodium falciparum. Antimicrob Agents Chemother. 2006;50:3124-31.

36. Yeh E, DeRisi JL. Chemical rescue of malaria parasites lacking an apicoplast defines organelle function in blood-stage Plasmodium falciparum. PLoS Biol. 2011;9:1001138.

37. Briolant S, Almeras L, Belghazi M, Boucomont-Chapeaublanc E, Wurtz $\mathrm{N}$, Fontaine $\mathrm{A}$, et al. Plasmodium falciparum proteome changes in response to doxycycline treatment. Malar J. 2010;9:141.

38. Ruiz Sanchez F, Casillas J, Paredes M, Lelazquez J, Riebeling QB. Terramycin in malaria therapy. Pan Am Med Womans J. 1952;59:10-5.

39. Grande EN, Sanchez AR, Sanchez FR. The treatment of malaria with tetracycline. Antibiotic Med Clin Ther. 1956;3:193-6.

40. Clyde DF, Miller RM, DuPont HL, Hornick RB. Antimalarial effects of tetracyclines in man. J Trop Med Hyg. 1971;74:238-42.

41. Willerson D Jr, Rieckmann KH, Carson PE, Frischer H. Effects of minocycline against chloroquine-resistant falciparum malaria. Am J Trop Med Hyg. 1972;21:857-62.

42. Garnham PC, Warren M, Killick-Kendrick R. The action of 'terramycin' on the primary exoerythrocytic development of Plasmodium vivax and Plasmodium cynomolgi ceylonensis. J Trop Med Hyg. 1971;74:2-35.

43. Kumar A, Dutta GP. Tissue schizontocidal activity of minocycline against a relapsing malaria parasite Plasmodium cynomolgi B. Indian J Med Res. 1987;85:519-21.

44. Kumar A, Dutta GP. Antimalarial activity of demeclocycline against Plasmodium cynomolgi bastianellii in rhesus monkeys. Ann Trop Med Parasitol. 1989;83:199-206.

45. Marussig M, Motard A, Renia L, Baccam D, Lebras J, Charmot G, Mazier D. Activity of doxycycline against preerythrocytic malaria. J Infect Dis. 1993;168:1603-4.

46. Shmuklarsky MJ, Boudreau EF, Pang LW, Smith JI, Schneider I, Fleckenstein $L$, et al. Failure of doxycycline as a causal prophylactic agent against Plasmodium falciparum malaria in healthy nonimmune volunteers. Ann Intern Med. 1994;120:294-9.

47. Rieckmann KH, Yeo AE, Davis DR, Hutton DC, Wheatley PF, Simpson R. Recent military experience with malaria chemoprophylaxis. Med J Aust. 1993;158:446-9.

48. Orlandi-Pradines E, Penhoat K, Durand C, Pons C, Bay C, Pradines B, et al. Antibody responses to several malaria pre-erythrocytic antigens as a marker of malaria exposure among travelers. Am J Trop Med Hyg. 2006;74:979-85.

49. Geary TG, Divo AA, Jensen JB. Stage specific actions of antimalarial drugs on Plasmodium falciparum in culture. Am J Trop Med Hyg. 1989;40:240-4.

50. Legrand E, Volney B, Meynard J-B, Mercereau-Puijalon O, Esterre P. In vitro monitoring of Plasmodium falciparum drug resistance in French Guiana: a synopsis of continuous assessment from 1994 to 2005. Antimicrob Agents Chemother. 2008;52:288-98.

51. Briolant S, Wurtz N, Zettor A, Rogier C, Pradines B. Susceptibility of Plasmodium falciparum isolates to doxycycline is associated with pftetQ sequence polymorphisms and pftetQ and pfmdt copy numbers.J Infect Dis. 2010;201:153-9.

52. Pradines B, Spiegel A, Rogier C, Tall A, Mosnier J, Fusai T, et al. Antibiotics for prophylaxis of Plasmodium falciparum infections: in vitro activity of doxycycline against Senegalese isolates. Am J Trop Med Hyg 2000;62:82-5

53. Pradines B, Rogier C, Fusai T, Mosnier J, Daries W, Barret E, et al. In vitro activities of antibiotics against Plasmodium falciparum are inhibited by iron. Antimicrob Agents Chemother. 2001;45:1746-50.

54. Pang LW, Limsomwong N, Boudreau EF, Singharaj P. Doxycycline prophylaxis for falciparum malaria. Lancet. 1987;i:1161-4.

55. Pang L, Limsomwong N, Singharaj P. Prophylactic treatment of vivax and falciparum malaria with low-dose doxycycline. J Infect Dis. 1988;158:1124-7.

56. Watanasook C, Singharaj P, Suriyamongkol V, Karwacki JJ, Shanks D, Phintuyothin P, et al. Malaria prophylaxis with doxycycline in soldiers deployed to the Thai-Kampuchean border. Southeast Asian J Trop Med Public Health. 1989;20:61-4.
57. Shanks GD, Edstein MD, Suriyamongkol V, Timsaad S, Webster HK. Malaria chemoprophylaxis using proguanil/dapsone combinations on the Thai-Cambodian border. Am J Trop Med Hyg. 1992;46:643-8.

58. Taylor WR, Richie TL, Fryauff DJ, Picarima H, Ohrt C, Tang D, et al. Malaria prophylaxis using azithromycin: a double-blind, placebo-controlled trial in Irian Jaya, Indonesia. Clin Infect Dis. 1999;28:74-81.

59. Shanks GD, Barnett A, Edstein MD, Rieckmann KH. Effectiveness of doxycycline combined with primaquine for malaria prophylaxis. Med J Aust. 1995;162:306-7.

60. Weiss WR, Oloo AJ, Johnson A, Koech D, Hoffman SL. Daily primaquine is effective for prophylaxis against falciparum malaria in Kenya: comparison with mefloquine, doxycycline, and chloroquine plus proguanil. J Infect Dis. 1995;171:1569-75.

61. Migliani R, Josse R, Hovette R, Keundjian A, Pagès F, Meynard JB, et al. Le paludisme vu des tranchées: le cas de la Côte d'Ivoire en 2002-2003. Med Trop. (Mars). 2003;63:282-6.

62. Migliani R, Ollivier L, Romand O, Verret C, Haus-Cheymol R, Todesco A, et al. Paludisme chez les militaires français en Côte d'Ivoire de 1998 à 2006. Bull Epidemiol Hebdom. 2008;23-24:209-12.

63. Shanks GD, Roessler P, Edstein M, Rieckmann KH. Doxycycline for malaria prophylaxis in Australian soldiers deployed to United Nations missions in Somalia and Cambodia. Mil Med. 1995;160:443-4.

64. Madamet M, Gaillard T, Velut G, Ficko C, Houzé P, Bilicky C, et al. Malaria prophylaxis failure with doxycycline, Central African Republique, 2014. Emerg Infect Dis. 2015;21:1485-6.

65. Pukrittayakamee $S$, Clemens R, Chantra A, Nontprasert A, Luknam T, Looareesuwan $\mathrm{S}$, et al. Therapeutic responses to antibacterial drugs in vivax malaria. Trans R Soc Trop Med Hyg. 2001;95:524-8.

66. Rieckmann KH, Powell RD, McNamara JV, Willerson D Jr, Lass L, Frischer H, et al. Effects of tetracycline against chloroquine-resistant and chloroquinesensitive Plasmodium falciparum. Am J Trop Med Hyg. 1971;20:811-5.

67. Laing AB. The effect of tetracycline on Plasmodium falciparum in the Gambia. Trans R Soc Trop Med Hyg. 1972;66:956-7.

68. Ponnampalam JT. Doxycycline in the treatment of falciparum malaria among aborigine children in West Malaysia. Trans R Soc Trop Med Hyg 1981;75:372-7.

69. Chin W, Intraprasert R. The evaluation of quinine alone or in combination with tetracycline and pyrimethamine against falciparum malaria in Thailand. Southeast Asian J Trop Med Public Health. 1973;4:245-9.

70. Colwell EJ, Hickman RL, Kosakal S. Quinine-tetracycline and quininebactrim treatment of acute falciparum malaria in Thailand. Ann Trop Med Parasitol. 1973;67:125-32

71. Noeypatimanond S, Malikul S, Benjapong W, Duriyananda D, Ungkasrithongkul M. Treatment of Plasmodium falciparum malaria with a combination of amodiaquine and tetracycline in Central Thailand. Trans R Soc Trop Med Hyg. 1983;77:338-40.

72. Pukrittayakamee S, Chotivanich K, Chantra A, Clemens R, Looareesuwan S, White NJ. Activities of artesunate and primaquine against asexualand sexual-stage parasites in falciparum malaria. Antimicrob Agents Chemother. 2004;48:1329-34.

73. Alecrim MG, Lacerda MV, Mourão MP, Alecrim WD, Padilha A, Cardoso $B S$, et al. Successful treatment of Plasmodium falciparum malaria with a six-dose regimen of artemether-lumefantrine versus quinine-doxycycline in the Western Amazon region of Brazil. Am J Trop Med Hyg. 2006;74:20-5.

74. Watt G, Loesuttivibool L, Shanks GD, Boudreau EF, Brown AE, Pavanand $\mathrm{K}$, et al. Quinine with tetracycline for the treatment of drug-resistant falciparum malaria in Thailand. Am J Trop Med Hyg. 1992;47:108-11.

75. Jacobs RL, Koontz LC. Plasmodium berghei: development of resistance to clindamycin and minocycline in mice. Exp Parasitol. 1976;40:116-23.

76. Divo AA, Geary TG, Jensen JB. Oxygen- and time-dependent effects of antibiotics and selected mitochondrial inhibitors on Plasmodium falciparum in culture. Antimicrob Agents Chemother. 1985;27:21-7.

77. Pascual A, Basco LK, Baret E, Amalvict R, Travers D, Rogier C, et al. Use of the atmospheric generators for capnophilic bacteria Genbag-CO2 for the evaluation of in vitro Plasmodium falciparum susceptibility to standard anti-malarial drugs. Malar J. 2011;10:8.

78. Fall B, Pascual A, Sarr FD, Wurtz N, Richard V, Baret E, et al. Plasmodium falciparum susceptibility to anti-malarial drugs in Dakar, Senegal, in 2010: an ex vivo and drug resistance molecular markers study. Malar J. 2013;12:107. 
79. Briolant S, Baragatti M, Parola P, Simon F, Tall A, Sokhna C, et al. Multinormal in vitro distribution model suitable for the distribution of Plasmodium falciparum chemosusceptibility to doxycycline. Antimicrob Agents Chemother. 2009;53:688-95.

80. Gaillard T, Briolant S, Houzé S, Baragatti M, Wurtz N, Hubert V, et al. PftetQ and pfmdt copy numbers as predictive molecular markers of decreased ex vivo doxycycline susceptibility in imported Plasmodium falciparum malaria. Malar J. 2013;12:414.

81. Gaillard T, Fall B, Tall A, Wurtz N, Diatta B, Lavina M, et al. Absence of association between ex vivo susceptibility to doxycycline and pftetQ and pfmdt copy numbers in Plasmodium falciparum isolates from Dakar. Senegal. Clin Microbiol Infect. 2012;18:238-40.

82. Fall B, Diawara S, Sow K, Baret E, Diatta B, Fall KB, et al. Ex vivo susceptibility of Plasmodium falciparum isolates from Dakar, Senegal, to seven standard anti-malarial drugs. Malar J. 2011;10:310.

83. Achieng AO, Ingasia LA, Juma DW, Cheruiyot AC, Okudo CA, Yeda RA, et al. Reduced in vitro doxycycline susceptibility in Plasmodium falciparum field isolates from Kenya is associated with PfTetQ KYNNNN sequence polymorphism. Antimicrob Agents Chemother. 2014;58:5894-9.

84. Gaillard T, Sriprawat K, Briolant S, Wangsing C, Wurtz N, Baragatti M, et al. Molecular markers and in vitro susceptibility to doxycycline in Plasmodium falciparum isolates from Thailand. Antimicrob Agents Chemother. 2015;59:5080-3.

85. Quashie NB, Duah NO, Abuaku B, Quaye L, Ayanful-Torgby R, Akwoviah GA, et al. A SYBR Green 1-based in vitro test of susceptibility of Ghanaian Plasmodium falciparum clinical isolates to a panel of anti-malarial drugs. Malar J. 2013;12:450.

86. Wein S, Maynadier M, Tran Van Ba C, Cerdan R, Peyrottes S, Fraisse L, et al. Reliability of antimalarial sensitivity tests depends on drug mechanism of action. J Clin Microbiol. 2010;48:1651-60.

87. Paulsen IT, Brown MH, Skurray RA. Proton-dependent multidrug efflux systems. Microbiol Rev. 1996;60:575-608.

88. Yang W, Moore IF, Koteva KP, Bareich DC, Hughes DW, Wright GD. TetX is a flavin-dependent monooxygenase conferring resistance to tetracycline antibiotics. J Biol Chem. 2004;279:52346-52.

89. Dantley KA, Dannelly HK, Burdett V. Binding interaction between Tet(M) and the ribosome: requirements for binding. J Bacteriol. 1998;180:4089-92.

90. Trieber CA, Burkhardt N, Nierhaus KH, Taylor DE. Ribosomal protection from tetracycline mediated by Tet $(\mathrm{O})$ : Tet $(\mathrm{O})$ interaction with ribosomes is GTP-dependent. Biol Chem. 1998;379:847-55.

91. Briolant S, Fusai T, Rogier C, Pradines B. Tetracycline antibiotics in malaria. Open Trop Med J. 2008;1:31-46.

92. Mura M, Briolant S, Donato D, Volney B, Pelleau S, Musset LA, et al. Absence of correlation between ex vivo susceptibility to doxycycline and pfteQ-pfmdt gene polymorphism in French Guiana. Malar J. 2015;14:286.

93. Gaillard T, Wurtz N, Houzé S, Sriprawat K, Wangsing C, Hubert V, et al. Absence of association between Plasmodium falciparum small sub-unit ribosomal RNA gene mutations and in vitro decreased susceptibility to doxycycline. Malar J. 2015;14:348.

94. Gerrits MM, de Zoete MR, Arents NLA, Kuipers EJ, Kusters JG. 16S rRNA mutation-mediated tetracycline resistance in Helicobacter pylori. Antimicrob Agents Chemother. 2002;46:2996-3000.

95. Trieber CA, Taylor DE. Mutations in the 16S rRNA genes of Helicobacter pylori mediate resistance to tetracycline. J Bacteriol. 2002;184:2131-40.

96. Ross Jl, Eady EA, Cove JH, Cunliffe WJ. 16S rRNA mutation associated with tetracycline resistance in a gram-positive bacterium. Antimicrob Agents Chemother. 1998;42:1702-5.

97. Dailidiene D, Bertoli MT, Miciuleviciene J, Mukhopadhyay AK, Dailide G, Pascasio MA, et al. Emergence of tetracycline resistance in Helicobacter pylori: multiple mutational changes in 16S ribosomal DNA and other genetic loci. Antimicrob Agents Chemother. 2002;46:3940-6.

98. Ribeiro ML, Gerrits MM, Benvengo YHB, Berning M, Godoy APO, Kuipers EJ, et al. Detection of high-level tetracycline resistance in clinical isolates of Helicobacter pylori using PCR-RFLP. FEMS Immunol Med Microbiol. 2004;40:57-61.

99. Wilson RJ, Denny PW, Preiser PR, Rangachari K, Roberts K, Roy A, et al. Complete gene map of the plastid-like DNA of the malaria parasite Plasmodium falciparum. J Mol Biol. 1996;261:155-72.

100. Miotto O, Almagro-Garcia J, Manske M, Macinnis B, Campino S, Rockett KA, et al. Multiple populations of artemisinin-resistant Plasmodium falciparum in Cambodia. Nat Genet. 2013:45:648-55.
101. Ménard S, Ben Haddou T, Ramadani AP, Ariey F, Iriart X, Beghain J, et al. Induction of multidrug tolerance in Plasmodium falciparum by extended artemisinin pressure. Emerg Infect Dis. 2015;21:1733-41.

102. Ariey F, Witkowski B, Amaratunga C, Beghain J, Langlois AC, Khim N, et al. A molecular marker of artemisinin-resistant Plasmodium falciparum malaria. Nature. 2014;505:50-5.

103. Ohrt C, Richie TL, Widjaja H, Shanks GD, Fitriadi J, Fryauff DJ, et al. Mefloquine compared with doxycycline for the prophylaxis of malaria in Indonesian soldiers. A randomized, double-blind, placebo-controlled trial. Ann Intern Med. 1997;126:963-72.

104. Andersen SL, Oloo AJ, Gordon DM, Ragama OB, Aleman GM, Berman $J D$, et al. Successful double-blinded, randomized, placebo-controlled field trial of azithromycin and doxycycline as prophylaxis for malaria in western Kenya. Clin Infect Dis. 1998;26:146-50.

105. Schwartz E, Regev-Yochay G. Primaquine as prophylaxis for malaria for nonimmune travelers: a comparison with mefloquine and doxycycline. Clin Infect Dis. 1999:29:1502-6.

106. Peragallo MS, Croft AM, Kitchener SJ. Malaria during a multinational military deployment: the comparative experience of the Italian, British and Australian Armed Forces in East Timor. Trans R Soc Trop Med Hyg. 2002;96:481-2.

107. Clyde DF, Miller RM, Music SI, McCarthy VC. Prophylactic and sporontocidal treatment of chloroquine-resistant Plasmodium falciparum from Vietnam. Am J Trop Med Hyg. 1971;20:1-5.

108. Taylor WR, Widjaja H, Richie TL, Basri H, Ohrt C, Tjitra, et al. Chloroquine/ doxycycline combination versus chloroquine alone, and doxycycline alone for the treatment of Plasmodium falciparum and Plasmodium vivax malaria in northeastern Irian Jaya, Indonesia. Am J Trop Med Hyg 2001;64:223-8.

109. Colwell EJ, Hickman RL, Kosakal S. Tetracycline treatment of chloroquine-resistant falciparum malaria in Thailand. JAMA. 1972;220:684-6.

110. Giboda M, Denis MB. Response of Kampuchean strains of Plasmodium falciparum to antimalarials: in vivo assessment of quinine and quinine plus tetracycline; multiple drug resistance in vitro. J Trop Med Hyg. 1988:91:205-11.

111. Looareesuwan S, Vanijanonta S, Viravan C, Wilairatana P, Charoenlarp $P$, Lasserre $R$, et al. Randomised trial of mefloquine-tetracycline and quinine-tetracycline for acute uncomplicated falciparum malaria. Acta Trop. 1994;57:47-53.

112. Looareesuwan S, Viravan C, Vanijanonta S, Wilairatana P, Charoenlarp $P$, Canfield CJ, et al. Randomized trial of mefloquine-doxycycline, and artesunate-doxycycline for treatment of acute uncomplicated falciparum malaria. Am J Trop Med Hyg. 1994;50:784-9.

113. Metzger W, Mordmüller B, Graninger W, Bienzle U, Kremsner PG. Sulfadoxine/pyrimethamine or chloroquine/clindamycin treatment of Gabonese school children infected with chloroquine resistant malaria. J Antimicrob Chemother. 1995;36:723-8.

114. Na-Bangchang K, Kanda T, Tipawangso P, Thanavibul A, Suprakob K, Ibrahim M, et al. Activity of artemether-azithromycin versus artemetherdoxycycline in the treatment of multiple drug resistant falciparum malaria. Southeast Asian J Trop Med Public Health. 1996;27:522-5.

115. Looareesuwan S, Viravan C, Webster HK, Kyle DE, Hutchinson DB, Canfield CJ. Clinical studies of atovaquone, alone or in combination with other antimalarial drugs, for treatment of acute uncomplicated malaria in Thailand. Am J Trop Med Hyg. 1996;54:62-6.

116. Duarte EC, Fontes CJ, Gyorkos TW, Abrahamowicz M. Randomized controlled trial of artesunate plus tetracycline versus standard treatment (quinine plus tetracycline) for uncomplicated Plasmodium falciparum malaria in Brazil. Am J Trop Med Hyg. 1996;54:197-202.

117. Bunnag D, Karbwang J, Na-Bangchang K, Thanavibul A, Chittamas S, Harinasuta T. Quinine-tetracycline for multidrug resistant falciparum malaria. Southeast Asian J Trop Med Public Health. 1996;27:15-8.

118. Pukrittayakamee S, Chantra A, Vanijanonta S, Clemens R, Looareesuwan S, White NJ. Therapeutic responses to quinine and clindamycin in multidrug-resistant falciparum malaria. Antimicrob Agents Chemother. 2000;44:2395-8.

119. Ejaz A, Haqnawaz K, Hussain Z, Butt R, Awan Zl, Bux H. Treatment of uncomplicated plasmodium falciparum malaria with quinine-doxycycline combination therapy. J Pak Med Assoc. 2007;57:502-5. 